This is an author produced version of a paper published in Regulatory Peptides. This paper has been peer-reviewed but does not include the final publisher proof-corrections or journal pagination.

Citation for the published paper:

Ohlsson B, Truedsson M, Djerf P, Sundler F.

"Oxytocin is expressed throughout the human gastrointestinal tract"

Regulatory Peptides, 2006, Vol: 135, Issue: 1-2, pp. 7-11.

http://dx.doi.org/10.1016/j.regpep.2006.03.008

Access to the published version may require journal subscription.

Published with permission from: Elsevier 
Short title: Oxytocin and the gastrointestinal tract

Revision 1, 060228

\title{
Oxytocin is expressed throughout the human gastrointestinal tract
}

\author{
Bodil Ohlsson $^{1}$, Mikael Truedsson ${ }^{1}$, Pauline Djerf ${ }^{2}$ \& Frank Sundler ${ }^{3}$
}

From the Department of Clinical Science, Gastroenterology ${ }^{1}$, Malmö, Department of

Surgery $^{2}$, Lund and Department of Experimental Medical Sciences, Division of Neuroendocrine Cell Biology ${ }^{3}$, Lund, Lund University, Sweden

Correspondence to: Bodil Ohlsson

Entrance 35

20502 Malmö

Sweden

Phone $+46+40331000$

Fax $+46+40336208$

Mail bodil.ohlsson@med.lu.se

Key words; oxytocin; oxytocin receptor; immunohistochemistry; gastrointestinal tract 


\begin{abstract}
Background/Aim: Several studies have described that oxytocin exerts stimulatory or inhibitory effects on gut functions. Recently, mRNA for oxytocin and its receptor was found throughout the entire human gastrointestinal (GI) tract. The aim of this study was to examine the cellular localization and distribution of the corresponding proteins.

Material \& Methods: Full-thickness biopsies from 24 patients, covering the entire GI tract, were collected during operations at the Department of Surgery in Malmö and Lund. The biopsies were taken from non-affected margins. The biopsies were fixed by immersion, rinsed in buffered sucrose, and kept frozen at $-70^{\circ} \mathrm{C}$. Indirect immunofluorescence with primary antibodies to oxytocin and its receptor was used.

Results: Oxytocin was expressed in nerve cell bodies and nerve fibres in the myenteric and submucous ganglia all along the GI tract. Immunoreactive nerve cell bodies in myenteric ganglia predominated in the proximal (antrum and duodenum) and distal gut, while those in the submucous ganglia were more numerous in the ileum and colon. The oxytocin receptor was not detectable by two different antibodies in any tissue in the GI tract.

Conclusion: Oxytocin is expressed in the myenteric and submucous ganglia and nerve fibres along the entire human GI tract. The role for oxytocin in the physiology and pathophysiology of the bowel remains to be settled.
\end{abstract}




\section{Introduction}

Oxytocin is a hormone with its most well known effect on myoepithelial cells and uterine smooth muscles in the responses associated with the milk ejection reflex and parturition. During the last years the possibility has been raised that oxytocin also contributes to the control of the gastrointestinal (GI) motility. Oxytocin is secreted into the blood in response to endogenous (after a fatty meal), and exogenous cholecystokinin (CCK) in women $[1,2]$. Intravenous infusion of oxytocin leads to increased colonic peristalsis, and to accelerated gastric emptying of a meal in healthy subjects $[3,4]$, whereas an oxytocin receptor antagonist delays the gastric emptying [5]. In contrast, gastric motility is inhibited in dogs and rats $[6,7,8]$. Oxytocin relaxes the ileum and caecum, while it has a contracting effect on colon, both in vitro $[9,10]$ and in vivo $[6,7,11]$.

Although there are divergent results in different species, the effects observed throughout the GI tract suggest that there may be receptors for oxytocin in the gut. We have recently found mRNA for oxytocin and its receptor throughout the human GI tract [12]. The aim of this study was to examine if the expressed mRNA also led to translation and expression of the corresponding proteins. 


\section{Subjects \& Methods}

The study was approved by the Ethics committee at Lund University. All patients gave written informed consent before the operation.

\section{Patients}

Full-thickness biopsies from all segments of the GI-tract were collected from 24 patients (7 females) undergoing surgery for gastric diseases. The age of the patients ranged from 48 to 86 years, with a mean age of $72.9 \pm 10.1$ years [12]. No patients underwent surgery solely for the purpose of this study. The biopsies are normal tissue from parts of resected intestine, usually the resection margins. The biopsies were fixed by immersion overnight in a mixture of $2 \%$ paraformaldehyde and $0.2 \%$ picric acid (Stefanini's fixative; $\mathrm{pH}$ 7.2), followed by repeated rinsing in $10 \%$ sucrose (Tyrode’s solution; phosphate buffer, $\mathrm{pH}$ 7.2), and kept frozen at $-70^{\circ} \mathrm{C}$ and then further processed for cryostat sectioning.

\section{Immunohistochemistry}

Indirect immunofluorescence, as earlier described [13], was used to investigate the localization of oxytocin and the oxytocin receptor. Specimens were frozen in dry ice and sectioned (10 $\mu \mathrm{m}$ thickness) in a cryostat. The sections were incubated overnight at $4^{\circ} \mathrm{C}$ with polyclonal rabbit anti-oxytocin antibodies (Research Diagnostics Inc, Flanders, NJ, USA), raised against a synthetic oxytocin (Sigma, St. Louis, MO, USA) conjugated to thyroglobulin, at a dilution of 1:2560. The antibodies display less than $1 \%$ cross-reactivity with arginine vasopressin. The primary antibodies were detected by incubation with a secondary fluorescein isothiocyanate (FITC)-conjugated swine anti-rabbit IgG antibody (DAKO, Copenhagen, Denmark). As controls served sections incubated with primary antibodies preabsorbed with antigen in excess $\left(100 \mu \mathrm{g}\right.$ of synthetic oxytocin (Syntocinon ${ }^{\circledR}$, Novartis, Täby, Sweden) per ml diluted antiserum), or with secondary antibodies alone. 
For localisation of the receptors, tissue sections were incubated overnight at $4^{\circ} \mathrm{C}$ with two different antibodies. Firstly, polyclonal rabbit anti-rat oxytocin receptor antibodies (Research Diagnostics Inc, Flanders, NJ, USA), raised against a 20 amino acid peptide sequence within the carboxy terminus (cytoplasmic) domain coupled to KLH, were used at a dilution of 1:2560. The antibodies display $85 \%$ cross-reactivity with human oxytocin receptor. The primary antibodies were detected by incubation with a secondary fluorescein isothiocyanate (FITC)-conjugated swine anti rabbit IgG antibody (DAKO, Copenhagen, Denmark). Secondly, a mouse monoclonal anti-human oxytocin receptor IgM antibody, 2F8, raised against the peptide corresponding to the $20^{\text {th }}$ to $40^{\text {th }}$ amino acids of the human receptor sequence [14], was used at a concentration of $10 \mu \mathrm{g} / \mathrm{ml}$. The antibody was a kind gift from Prof T Kimura, Osaka, Japan. After washing, sections were incubated with FITC-labelled anti-mouse IgM (Sigma) for $1 \mathrm{~h}$ at room temperature. As controls served sections incubated with primary antibodies preabsorbed with antigen in excess $(100 \mu \mathrm{g}$ of synthetic peptide (Agrisera, Vännäs, Sweden), per ml diluted antiserum), or with secondary antibodies alone.

Sections were examined in a Leica epifluorescence microscope (Ernst Leitz, Wetzlar, Germany). The amount of immunostained cells was counted in at least three sections from every patient and expressed as percentage of all nerve cell bodies in each ganglion profile. As there was a modest variation between patients, only the average value of staining is shown. 


\section{Results}

Oxytocin immunoreactivity was demonstrated in neuronal elements in the wall of the GI tract, both in the myenteric ganglia (Fig 1) and the submucous ganglia (Fig 2). Within the ganglia, both nerve cell bodies and nerve fibre varicosities were immunoreactive (Table 1). The frequency of oxytocin-immunoreactive myenteric nerve cell bodies varied among the different regions examined, and there was a tendency towards an increase in the number of nerve cells displaying oxytocin immunoreactivity cranially (stomach and duodenum) and caudally in the gut (data not shown). In contrast, the immunoreactivity in the submucous ganglia was more dominant in the ileum and colon than in the proximal parts. The immunoreactivity in the stomach was found in the antrum, whereas no oxytocin immunoreactivity was found in the fundus close to the cardia. Faintly immunostained nerve fibres were sometimes encountered in the circular smooth muscle (Fig 3). In duodenum also weakly immunoreactive mucosal nerve fibres were visible (data not shown).

Specific oxytocin receptor immunostaining could not be detected in any tissue in the GI tract. 


\section{Discussion}

In this study, we have for the first time shown the expression of oxytocin in the GI tract. We found a distinct expression of oxytocin in nerve cell bodies and fibres in both myenteric and submucous ganglia. This finding provides a morphological substrate for a role of locally produced oxytocin in the regulation of gut motility and mucosal functions.

Oxytocin receptors were not found in the present study. However, as mRNA for the oxytocin receptor was widely expressed [12], there may be an expression at levels below the detection limit with the antibodies and method used in the present study. On the other hand, the effects observed of oxytocin on the motility may be mediated by vasopressin receptors. The neurophyseal hormones vasopressin and oxytocin are cyclic nonapetides whose actions are mediated by stimulation of specific $G$ protein-coupled receptors currently classified into $\mathrm{V}_{1}$ - vascular, $\mathrm{V}_{2}-$ renal and $\mathrm{V}_{3}$-pituitary vasopressin receptors, and oxytocin receptors. Vasopressin is the ligand having the highest affinity for the human V-receptors, while oxytocin is the ligand with the highest affinity for the oxytocin receptor. However, there is cross-reactivity of the ligands to the receptors [15]. The expression of vasopressin receptors in the GI tract has yet to be examined.

The motility in the stomach, ileum and caecum was inhibited, while the motility in colon was stimulated, in several animal species [6-11]. When performing this study, we were not able to demonstrate any oxytocin receptors in the rat GI tract either (unpublished observation). This might explain why the effects evoked by oxytocin on gastric and intestinal motility in rat are suggested to be mediated by release of cholcystokinin (CCK) and CCK receptors, which in turn leads to motility inhibition in the proximal GI tract [16]. CCK is produced by endocrine cells in the proximal small intestine and is released into the blood [17]. The question is how oxytocin mediates this release of CCK, and the oxytocin receptor antagonist atosiban inhibits the release [16], if no oxytocin receptors are present in the GI 
tract. Theoretically, intraperitoneal oxytocin and atosiban injections may cross the blood-brain barrier [18] and exert central effects by activating respective inhibit vagal neurons in the dorsal vagal complex that are involved in the regulation of CCK secretion [19]. However, other, as yet unknown, mechanisms may be involved.

The presence of oxytocin in the myenteric plexus suggests an effect of oxytocin in enteric neurotransmission and could explain the effect of oxytocin on motility earlier observed, where intravenous infusion of oxytocin led to increased colonic peristalsis, and to accelerated gastric emptying of a meal in healthy women $[3,4]$, whereas the oxytocin receptor antagonist delayed the gastric emptying [5]. Activated terminals of enteric motorneurons and smooth muscle cells form functional units that release transmitters and mediate and transduce neural inputs into mechanical responses [20]. Oxytocin may be involved in this process. Above, it is described how oxytocin acts on the GI tract in rat by inducing CCK secretion [16]. It remains to determine how oxytocin exerts its effects on the human GI tract.

Oxytocin has been shown to have an analgetic effect. It increases the threshold for peripheral pain in rats [21] and visceral pain in patients with IBS during continuous infusion [22]. Clinically, it has been observed that children with recurrent abdominal pain have lower plasma concentrations of oxytocin than age-matched controls [23]. In a recently completed double-blind placebo-controlled study, there was a tendency towards less abdominal pain and discomfort in patients suffering from functional bowel disorders after oxytocin administration [24]. The analgetic effect has been ascribed to central effects as it is exerted by intracerebroventricular injection, and by peripheral administration in 1,000-fold higher doses [25]. Oxytocin is assumed to activate secondary mechanisms, as oxytocin receptor antagonists are unable to reverse the effects, while the opioid receptor antagonist naloxone does [25]. Also dorsal root ganglia, an important area for pain processing, express oxytocin receptors [26]. Our findings of oxytocin in the submucous ganglia of the gut may 
open for a role for oxytocin in modulation of sensory nerve transmission also locally in the bowel.

Another role for oxytocin in the bowel may be to regulate the release of peptides or non-peptide neurotransmitters. Oxytocin is known to stimulate the nitric oxide (NO) pathway in human endothelial cells [15] and the release of atrial natriuretic peptide (ANP) from rat heart [27]. Similar effects could be expected in the bowel wall. Such effects could modulate secretomotor- and vasomotor reflexes, as these reflexes are determined in submucous ganglia [28], and oxytocin is known to exert both vasoconstrictory and vasodilatating effects depending on the vessel localisation [29, 30].

In conclusion, oxytocin is expressed in neuronal elements in the human GI tract. The question is how oxytocin acts in these tissues, and to what extent oxytocin contributes to GI physiology, and if this peptide is involved in the pathophysiology of gastroenterological diseases.

Acknowledgements: We would like to thank Prof T Kimura for the gift of the anti-human oxytocin receptor antibody. We also want to thank all colleagues at the Departments of Surgery in Malmö and Lund for helpful assistance in collecting the samples. This study was supported by grants from the Novo Nordic Foundation and the Development Foundation of Region Skåne. 


\section{References}

[1] Ohlsson B, Forsling ML, Rehfeld JF, Sjölund K. Cholecystokinin leads to increased oxytocin secretion in healthy women. Eur J Surg 2002;168:114-118.

[2] Ohlsson B, Rehfeld JF, Forsling ML. Oxytocin and cholecystokinin secretion in women with colectomy. BMC Gasroenterology 2004;4:25, page 1-6.

[3] Petring OU. The effect of oxytocin on basal and pethidine-induced delayed gastric emptying. Br J Clin Pharmacol 1989;28:329-332.

[4] Ohlsson B, Ringström G, Abrahamsson H, Simrén M, Björnsson ES. Oxytocin stimulates colonic motor activity in healthy women. Neurogastroenterol Mot 2004;16:3340.

[5] Ohlsson B, Björgell O, Ekberg O, Darwiche G. The oxytocin/vasopressin receptor antagonist atosiban delays the gastric emptying of a semisolid meal compared to saline in human. BMC Gastroenterology, in press.

[6] Milenov K, Kasakov L. Effect of synthetic oxytocin on the motor and bioelectrical activity of the stomach and small intestines (in vivo). Acta Physiol et Pharmacol Bulg 1975;3-4:31-39.

[7] Milenov K, Barth T, Jost K, Kasakov L. Effect of deamino-dicarba-oxytocin and oxytocin on myoelectrical and mechanical activity of uterus, stomach and small intestine in dog. Endocrinol Experiment 1979;13:177-183.

[8] Flanagan LM, Olson BR, Sved AF, Verbalis JG, Stricker EM. Gastric motility in conscious rats given oxytocin and an oxytocin antagonist centrally. Brain Res 1992;578:256-260.

[9] Bisset GW, Lewis GP. A spectrum of pharmacological activity in some biologically active peptides. Brit J Pharmacol 1962;19:168-182. 
[10] Botting JH. An isolated preparation with a selective sensitivity to vasopressin. Brit J Pharmacol 1965;24:156-162.

[11] Levy B. The intestinal inhibitory response to oxytocin, vasopressin and bradykinin. J Pharmacol Exp Therap 1963;140:356-366.

[12] Monstein H-J, Grahn N, Truedsson M, Ohlsson B. Oxytocin and oxytocin receptor mRNA expression in the human gastrointestinal tract: A polymerase chain reaction study. Regul Pept 2004;119:39-44.

[13] Wierup N, Svensson H, Mulder H, Sundler F. The ghrelin cell: a novel developmentally regulated islet cell in the human pancreas. Regul Pept 2002;107:63-69. [14] Kimura T, Ito Y, Einspanier A, Tohya K, Nobunaga T, Tokugawa Y, Takemura M, Kubota Y, Ivell R, Matsuura N, Saji F, Murata Y. Expression and immunolocalization of the oxytocin receptor in human lactating and non-lactating mammary glands. Human Reproduction 1998;13:2645-2653.

[15] Thibonnier M, Conarty DM, Preston JA, Plesnicher CL, Dweik RA, Erzurum SC. Human vascular endothelial cells express oxytocin receptors. Endocrinology 1999;140:1301-1309.

[16] Wu C-L, Hung C-R, Chang F-Y, Pau K-Y, Wang PS. Pharmacological effects of oxytocin on gastric emptying and intestinal transit of a non-nutritive liquid meal in female rats. Naunyn-Schiedeberg's Arch Pharmacol 2003;367:406-413.

[17] Larsson LI, Rehfeld JF. Distribution of gastrin and CCK cells in the rat gastrointestinal tract. Evidence for the occurrence of three distinct cell types storing COOH-terminal gastrin immunoreactivity. Histochemistry 1978;58:23-31.

[18] Ermrich A, Barth T, Ruhle HJ, Skopkova J, Hrbas P, Landgraf R. On the blood-brain barrier to peptides: accumulation of labelled vasopressin, DesGlyNH $\mathrm{H}_{2}$ vasopressin and oxytocin by brain regions. Endocrinol Exp 1985;19:29-37. 
[19] McCann MJ, Rogers RC. Oxytocin excites gastric-related neurones in rat dorsal vagal complex. J Physiol 1990;428:95-108.

[20] Ward SM. Interstitial cells of Cajal in enteric neurotransmission. Gut 2000;47:40-43.

[21] Uvnäs-Moberg K, Bruzelius G, Alster P, Bileviciute I, Lundeberg T. Oxytocin increases and a specific oxytocin antagonist decreases pain threshold in male rats. Acta Physiol Scand 1992;144:487-488.

[22] Louvel D, Delvaux M, Felez A, Fiormonti J, Bueno L, Lazorthes Y, Frexinos J. Oxytocin increases thresholds of colonic visceral perception in patients with irritable bowel syndrome. Gut 1996;39:741-747.

[23] Alfven G. Plasma oxytocin in children with recurrent abdominal pain. JPGN 2004;38:513-517.

[24] Ohlsson B, Truedsson M, Bengtsson M, Torstensson R, Sjölund K, Björnsson ES, Simrèn M. Effects of long-term treatment with oxytocin in chronic constipation; a doubleblind, placebo-controlled pilot trial. Neurogastroenterol Mot 2005;17:697-704.

[25] Petersson M, Alster P, Lundeberg T, Uvnäs-Moberg K. Oxytocin increases nociceptive thresholds in a long-term perspective in female and male rats. Neurosci lett 1996;212:87-90.

[26] Yang Q, Wu ZZ, Li X, Li ZW, Wei JB, Hu QS. Modulation by oxytocin of ATPactivated currents in rat dorsal root ganglion neurons. Neuropharmacology 2002;43:910916.

[27] Gutkowska J, Jankowski M, Lambert C, Mukaddam-Daher S, Zinn HH, McCann SM. Oxytocin releases atrial natriuretic peptide by combining with oxytocin receptors in the heart. Proc Natl Acad Sci 1997;94:11704-11709.

[28] Guyton AC (ed). Textbook of medical physiology. Philadelphia: WB Saunders company 1986: 757. 
[29] Suzuki Y, Satoh S-C, Kimura M, Oyama H, Asano T, Shibuya M, Sugita K. Effects of vasopressin and oxytocin on canine cerebral circulation in vivo. J Neurosurg 1992;77:424-431.

[30] Stam WB, Van der Graaf PH, Saxena PR. Characterization of receptors mediating contraction of the rat isolated small mesenteric artery and aorta to arginine vasopressin and oxytocin. Brit J Pharmacol 1998;125:865-873. 


\section{Legends to figures}

Figure 1. Oxytocin immunoreactivity demonstrated in myenteric ganglia in nerve cell bodies and fibres; strongly stained fibres surround small negative nerve cell bodies.

Figure 2. Oxytocin immunoreactivity demonstrated in submucous ganglia in nerve cell bodies and fibres.

Figure 3. Oxytocin immunoreactivity demonstrated in nerve fibres dispersed in the smooth muscle. 
Table 1. The expression of oxytocin in the gastrointestinal tract

\begin{tabular}{|c|l|l|l|l|}
\hline & Stomach & Duodenum & Ileum & Colon \\
\hline $\begin{array}{c}\text { Myenteric plexus } \\
\text { Ganglion }\end{array}$ & + & + & + & + \\
Nerve fibres & Sparsely & Expressed & Expressed & Expressed \\
\cline { 2 - 6 } & expressed & & & \\
Ganglion & - & & & +++ \\
Nerve fibres & Sparsely & Expressed & Expressed & Expressed \\
\cline { 2 - 6 } & expressed & & & \\
\hline
\end{tabular}

- = $0 \%,(+)<10 \%,+=10-30 \%,++=30-50 \%,+++=50-70 \%$ of cells containing a nucleus

were stained for oxytocin. As non-stained nerve fibres are very difficult to discover, no quantification was performed in these. 
